\title{
O excremento de vaca na alimentação de pintos em crescimento (*)
}

\author{
ARMANDO BERGAMIN
}

Eng. Agr.

INDICE

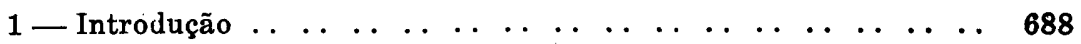

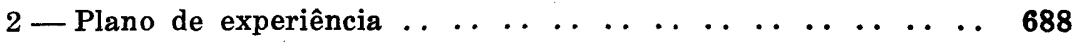

3 - Discussão e conclusões .. . . . . . . . . . . . . . . . . . . . 689

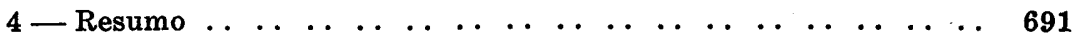

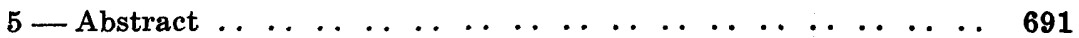

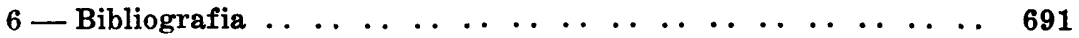

(*) Trabalho da Seção de Avicultura e Cunicultura. 


\section{1 - INTRODUÇÃO}

HAMMOND (2) em uma experiência constatou a ação benéfica do excremento de vaca sôbre o crescimento de pintos submetidos a uma alimentação deficiente em riboflavina, e que o excremento não tem ação nociva sôbre o crescimento quando adicionado á uma ração completa e balanceada, acrescentando ainda que o excremento possue um fator que provoca o desenvolvimento da crista em ambos os sexos.

O mesmo autor, no referido trabalho faz citação de vários autores que constataram que os ruminantes, sobretudo os bovinos, quando alimentados com ração contendo os ingredientes comumente usados, têm a faculdade de sintetisarem no rumen a tiamina, riboflavina, peridoxina, ácido pantotenico, ácido nicotinico e biotina.

HAMMOND (3) relatou que o excremento de vaca substtituiu sem prejuizo a farinha de folhas de alfafa em ração normal para peruzinhos em crescimento.

TURNER (5) constatou também essa ação sôbre o crescimento de pintos que receberam 5 e $10 \%$ de excremento de vaca em rações normais, atribuindo parte dêsse resultado à presença de um hormonio masculino no excremento.

PALAFOX e ROSENBERG (4) conseguiram resultados satisfatórios sôbre a produção de ovos, incubabilidade e pêso do corpo, usando rações contendo 5 e $10 \%$ de excremento de vaca.

EWING (1) admite a existência de um fator animal (A. P. F.) de crescimento nas fezes de vaca e cita trabalhos de varios autores nesse sentido.

\section{2 - PLANO DA EXPERIENCIA}

Conhecendo e existência dêsse fator de crescimento no excremento de vaca ocorreu-nos verificar si o mesmo seria capaz de substituir, em uma ração, toda proteina de origem animal e nara isso tomamos as 2 seguintes rações: 
Ração A - Testemunha

$45 \%$ Milho (quirera fina)

$10 \%$ Farinha de carne $(40 \%)$

$9 \%$ Refinazil

$9 \%$ Farelo de amendoim

$7 \%$ Farelinho de arroz

$20 \%$ Farelo de trigo

2,5 ks Farinha de ostra

$1 \mathrm{k}$ Sal
Ração B - Tratamento

$45 \%$ Milho (quirera fina)

$10 \%$ Farelo de algodão

$9 \%$ Refinazil

$9 \%$ Farelo de amendoim

$7 \%$ Farelinho de arroz

$20 \%$ Farelo de trigo

2 ks Excremento de vaca

2,5 ks Farinha de ostra

$1 \mathrm{k}$ Sal

Como se vê nas rações acima, a proteina animal fornecida pela farinha de carne foi substituida pelo farelo de torta de algodão na ração de experiência, recebendo esta, como adicional, $2 \mathrm{kgs}$ de excremento de vaca. Ás 2 rações foram adicionados $2,5 \mathrm{kgs}$ de farinha de ostra e $1 \mathrm{~kg}$ de sal $(\mathrm{NaCl})$ fino.

Para a experiência foram formados 2 lotes de 37 franguinhos Rhode Island Red com 40 dias de idade e colocados em 2 compartimentos de um dos pinteiros da Seção de Avicultura.

O excremento de vaca foi colhido fresco e secado ao ar livre, sob a ação dos raios solares e depois triturado para ser incorporado à ração. Os franguinhos 'tiveram à sua disposição o alimento colocado em comedouros e do qual se serviam à vontade e a medida de suas necessidades.

Para controle da experiência as aves foram pesadas inicialmente e depois semanalmente, num total de 7 pesagens.

\section{3 - DICUSSÃO E CONCLUSÕES}

Inicialmente os pintos estavam com bom aspecto e satisfatório desenvolvimento para a idade, e os 2 lotes foram organisados de forma a haver um equilíbrio no pêso médio, como pode ser verificado no quadro anexo. Durante as semanas de duração da experiência, além do controle do pêso, foi feita uma rigorosa observação do comportamento das aves e observamos não ter havido nada que demonstrasse ação nociva do excremento de vaca, assim como não se ressentiram os franguinhos com a ausência de proteina de origem animal na ração de tratamento.

Como a análise estatística (vêr quadro) não revelou diferença e considerando ainda que os franquinhos do lote de tratamento tiveram em todas as pesadas um aumento progressivo do pêso médio podemos concluir que o excremento de vaca supriu satisfatóriamente a ausência de farinha de carne. 


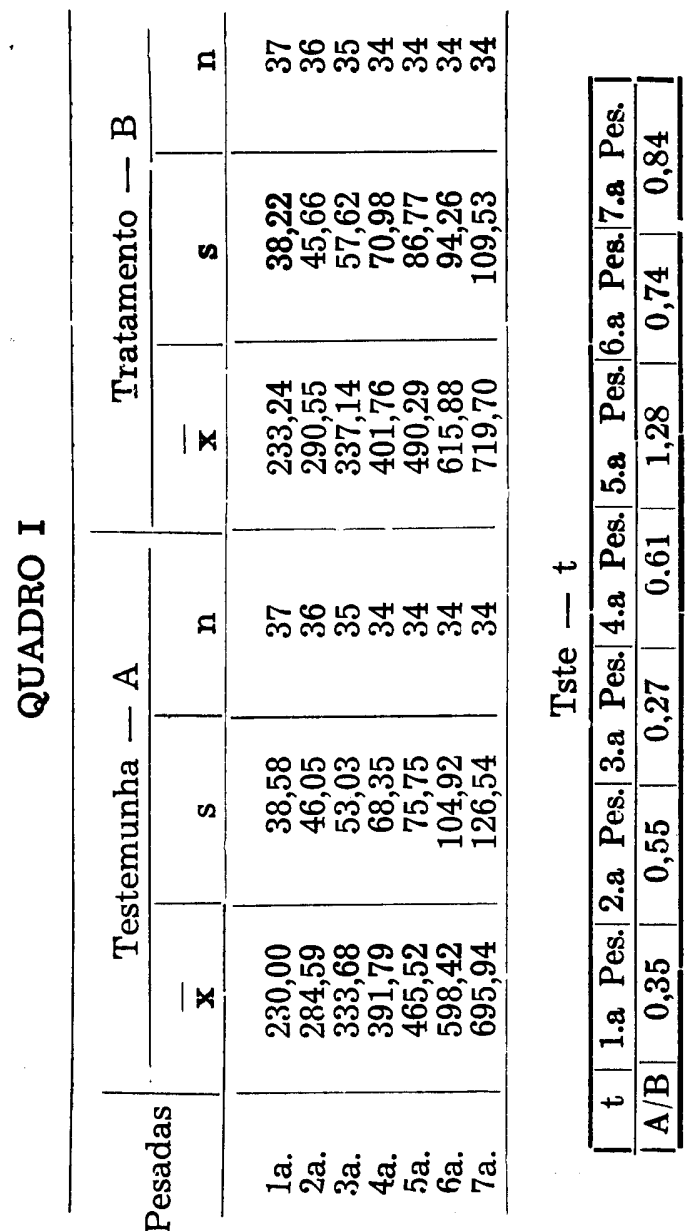

A mortalidade nos 2 lotes foi a mesma, isto é, de 3 aves cada um, o que nos leva a considerar que a causa tenha sido por motivos extranhos à experiência.

Estas conclusões não são definitivas e estão portanto sujeitas a confirmação, todavia êstes resultados preliminares nos levam a crêr nas possibilidades do emprêgo das fezes de bovinos para substituir os alimentos fornecedores de proteina animal nas rações de crescimento de pintos, trazendo aos avicultores reais vantagens econômicas, pois enquanto as fezes quasi nada custam, e são facilmente conseguidas em qualquer região, as tortas vegetais que podem ser usadas para substituir pêso a pêso a farinha de carne, são compradas por um preço extraordinàrimente mais baixo. 


\section{4 - RESUMO}

Foram tomados 2 lotes de pintos Rhode Island Red de 40 dias de idade que foram submetidos, o lote $\mathrm{A}$ a uma alimentação com ração sem proteina de origem animal, na qual a farinha de carne foi substituida por igual quantidade de farelo de torta de sementes de algodão, e adicionada à mesma 2 quilos de excremento de vaca, colhido fresco, secado ao sol e triturado; o lote $B$, que serviu de testemunha continha os mesmos ingredientes, com exceção de excremento de vaca e da torta de algodão, em lugar da qual figurava a farinha de carne.

Alimentadas durante 6 semanas as aves se comportaram de maneira idêntica, acusando as do lote $\mathrm{A}$ um aumento leve $\mathrm{e}$ progressivo do pêso médio, embora sem diferença estatística.

O excremento de vaca foi satisfatório e supriu as deficiências da ração de tratamento em certos amino ácidos só presentes em proteinas de origem animal como a farinha de carne.

\section{5 - ABSTRACT}

The effect of cow manure as substitute of animal protein on chick growth was studied in the present paper.

The results so far obtained seems to indicate a favorable action of cow manure. However, the difference between the lots compared could not be checked with the usual statistical methods.

\section{6 - BIBLIOGRAFIA}

1-EWING, W. R., 1951 - Poultry Nutrion. South Pasadena, California.

2 - HAMMOND, J. C., 1942 - Cow Manure as a Source of Certain Vitamins for Growing Chickens. Poultry Science, 21: 554-559.

3 - HAMMOND, J. C., 1944 - Cow Manure as an Ingredient of Turkey Diets. Poultry Science, 23: 358.

4-PALAFOX, A. L. e M. M. ROSENBERG - Effect of Feeding Cow Manure to New Hampshire Pullets on Egg Production, Hatchability and Body. Weight. Hawaii Agricultural Experiment Station of the University of Hawaii. June 1949. Honolulu, T. $H$.

5 - TURNER, C. W., 1947 - Dried Lactating Cow Manure in the Ration of Growing Chickens. Poultry Science, 26 : 143-149. 
